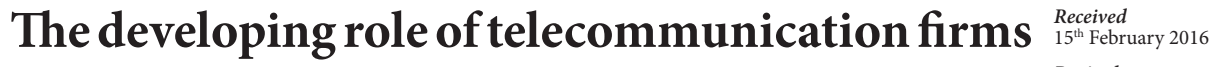

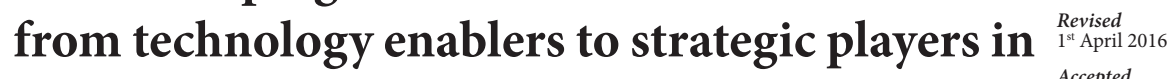 the smart factory

\author{
Paola Pisano - Marco Pironti - Lia Tirabeni - Davide Sola \\ Giovanni Scarso Borioli
}

\begin{abstract}
Purpose of the paper: The aim of this research is to investigate the role of telecommunication firms as technology partners in smart factory deployment and the potential impact on their own business model.

Methodology: We adopted a qualitative methodology based on multiple-case study analysis with the purpose of theory-building.

Results: i) Identification of three business model trajectories that are triggered by smart factory deployment both for recipient firms and for technology enabling firms; (ii) proposition of a directional framework that enables both smart factory recipient firms and technology partners to understand their options both in terms of Smart factory deployment and business model options and of the interconnections between them.

Research limitations: Selected cases have been used according to the state of development of the project. A larger number of cases, as well as a more in depth analysis, would increase confidence in the findings.

Practical implications: Identification of unexplored opportunities in the new, smart factory deployment paradigm that could transform the business model of the recipient firm as well as the role of the technology partners.

Originality of the paper: We identify the central role of the technology partners focusing on Telecommunication companies, who can enable the evolution of the business model transformation of recipient firms as well as its own. Moreover, the identification of the ownership and accessibility of data produced by the Smart factory is considered the main barrier for technology partners to make their business model evolve beyond business model trajectories.
\end{abstract}

Key words: smart factory; Telcos; business models; innovation

\section{Introduction}

In the current global competition scenario, the manufacturing sector is facing the challenge and the opportunity provided by new technologies, within the Industry 4.0 paradigm, to develop their business models towards a new concept of intelligent factory. Their aim is to bring together three strategic objectives which are often in conflict with each other in "traditional" business models: 
sinergie Vol. 35, N. 103, 2017
1) cost leadership through efficiency and lean processes;

2) differentiation through product innovation including the development of value added services;

3) sustainability through innovation of business model components in order to maintain an advantage over competitors from emerging countries and / or adjacent spaces.

New players from other sectors are entering this space as a result of the convergence enabled by digital technologies. Examples from the automotive sector may be found in the large investments in R \& D IT made by companies such as Google, Apple and Tesla.

The term "smart factory", used by both industrial practitioners and scholars, has no consistent definition. Other interchangeable terms are: factory of the future, Industry 4.0, factory of things, integrated or smart industry, and smart manufacturing (Radziwon et al., 2014).

Radziwon et al. (2014, p. 1187) suggest that a smart factory is "a manufacturing solution that provides such flexible and adaptive production processes that will solve problems arising on a production facility with dynamic and rapidly changing boundary conditions in a world of increasing complexity. This special solution could on the one hand be related to automation, understood as a combination of software, hardware and/or mechanics, which should lead to optimization of manufacturing resulting in reduction of unnecessary labour and waste of resource. On the other hand, it could be seen in a perspective of collaboration between different industrial and nonindustrial partners, where the smartness comes from forming a dynamic organization".

The smart factory is based on the Cyber-Physical Systems concept (a fusion of the physical and virtual worlds), the Internet of Things and the Internet of Services, which will have a disruptive impact on every aspect of manufacturing companies (Almada-Lobo, 2015). With its emphasis on manufacturing and logistics processes, it can be understood as a subset of the Industrial Internet, which is expanded from a product life-cycle perspective (Hermann, Pentek, and Otto, 2016)

Developments in the smart factory production paradigm have tended to be characterised by a mainly bottom-up approach. This usually involves individual companies looking for answers to specific production problems, leading to solutions which are difficult for other companies to replicate. To date, there has been a lack of top down, systemic initiatives to facilitate a large scale redesign of the sector that would make a significant contribution to the creation of value for all those involved.

The smart factory paradigm can be broken down into several themes: (i) systems to enable customized production; (ii) strategies, methods and tools to promote sustainability; (iii) systems for the enhancement of the role of the people in factories (iv) high efficiency production systems; (v) innovative production processes; (vi) production systems that can evolve and adapt; (vii) strategies and management approaches to develop nextgeneration production systems (Industries ratio 4.0., 2014).

There is an increasing focus on this emerging paradigm, which takes the form of initiatives that unite different actors from the world of production but also from other sectors such as telecommunications, the service sector 
and universities. People and organizations from different backgrounds are coming together in order to develop new propositions for the market, long-term investment plans, reference architecture and a regulatory and legislative framework capable of coping with the new and emerging requirements of technology and production. In Europe, various initiatives exist to support the factory of the future, including, the highly structured and organized German project Industrie 4.0, the United Kingdom's IoT UK, Fabbrica Intelligente in Italy and the European Factory of the Future Research Association which brings investments and initiatives together at a European level. Deutsche Telekom is one of the founders of the Industrie 4.0 platform, which has as its main objectives:

- the definition of a reference architecture for the smart factory;

- developing the management of complex industrial systems;

- the development of broadband as an infrastructure for the industry;

- security and data protection;

- management of new projects and design of case studies of smart factories;

- training and professional development to meet the smart factory's requirements;

- the definition of a regulatory framework.

The project is supported by a scientific advisory committee that includes members from the industry, research centers and universities, and the government.

Figure 1 provides a summary of the major European smart factory initiatives and shows the extent to which the various European nations are investing in the smart factory paradigm.

Fig. 1: Summary of main European Smart Factory initiatives

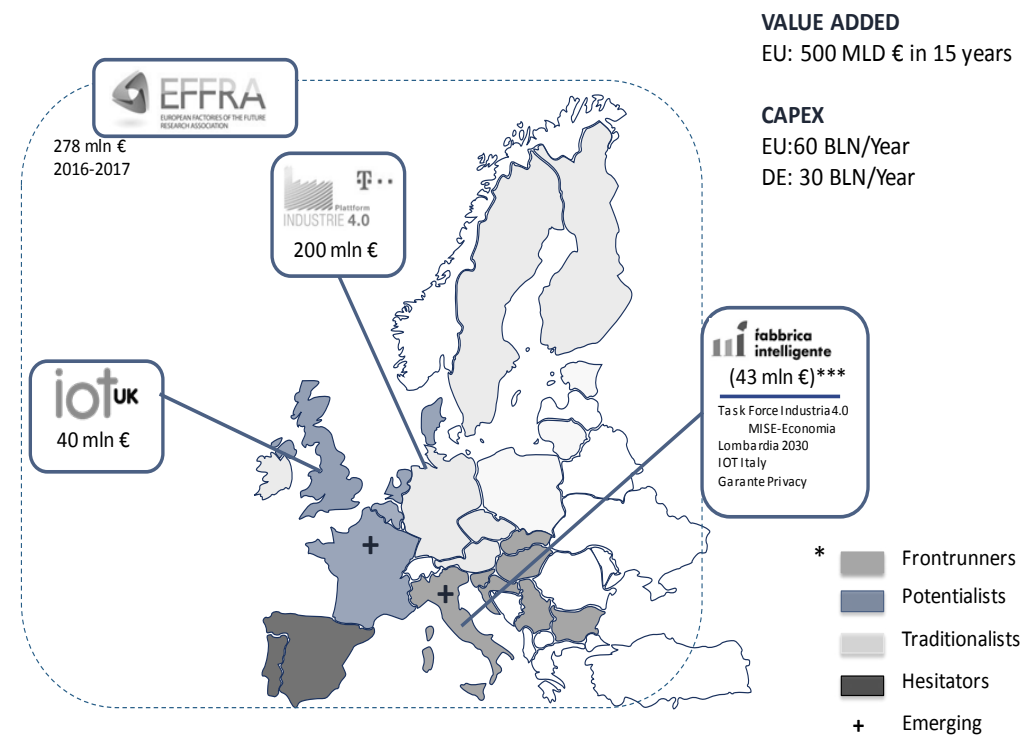

Paola Pisano Marco Piront Lia Tirabeni Davide Sola Giovanni Scarso Borioli The developing role of
The telecommunication firms from technology enablers to strategic players in the smart factory 
Sinergie Vol. 35, N. 103, 2017

To this end, a key enabling role could be taken on by telecommunication companies (Telcos) by creating collaborative platforms, communication standards and new value propositions designed to activate, strengthen and facilitate fresh projects and business initiatives. In turn, the Telcos could seize the new opportunities presented by the advent of the smart factory through the adoption of principles suited to this emerging trend.

To take on this dual role as enablers of smart factory experiences and actors at the same time within the new trend, the Telco must review traditional assumptions regarding business models to achieve a more flexible and innovative structure. This article intends to support and inform such a reflection.

The research question we set ourselves is:

"Does smart factory deployment provide additional business model options for adopting firms?"

Our hypotheses are:

1. that smart factory deployment will provide additional business models that are currently not accessible;

2. that there is a sequence of business model transformation driven by

a. availability of data and;

b. ability to create valuable insights.

We also set out the objective of investigating if such a research question is applicable to technology partners, with a focus on Telecommunication firms that are involved in the provision of smart factory deployment with an additional sub hypothesis;

c. access and rights of use of the data are the main constraint for the telecommunication partner to access new business model options that go beyond extending and defending the existing one.

The article is organized as follows: we start with an overview of our methodological approach, followed by a review of the literature in the domain of smart factory and innovative business models. Using the findings of the literature review as lenses, we then review a set of emerging business cases regarding the application of smart factory technologies. We conclude, in the results and discussion section, with the proposition of a framework which aims to enable recipients of smart factory technologies, as well as telecommunication firms, to understand their options in terms of business model choices and evolutions.

\section{Methodology and analysis process}

The methodology we selected to carry out the research is qualitative and case-based, leveraging on that of "Building Theory From Case Studies" (Eisendhardt, 1989). This methodology prescribes a first phase of literature review, to form an initial set of categories, concepts and constructs, followed by "iterative cycles of data-gathering and sense-making, or of action and reflection" (Reason and Goodwin, 1999), with evidence collected from 
multiple sources (both theoretical and empirical), including the use of case studies (Yin, 2008; Eisendhardt, 1989).

This iteration of data collection and sense-making allows the emergence of a conceptual model that is continuously tested against new evidence. In this process, therefore, "slices of data" are continuously contrasted, following a comparative method by searching for elements within the data that support or disprove emerging hypothetical relationships between Smart factory deployment and the availability of additional business model options. We enriched the approach by adopting a multiple-case approach in order to produce more robust and relevant results (Eisendhardt, 1989).

Fig. 2: The research process

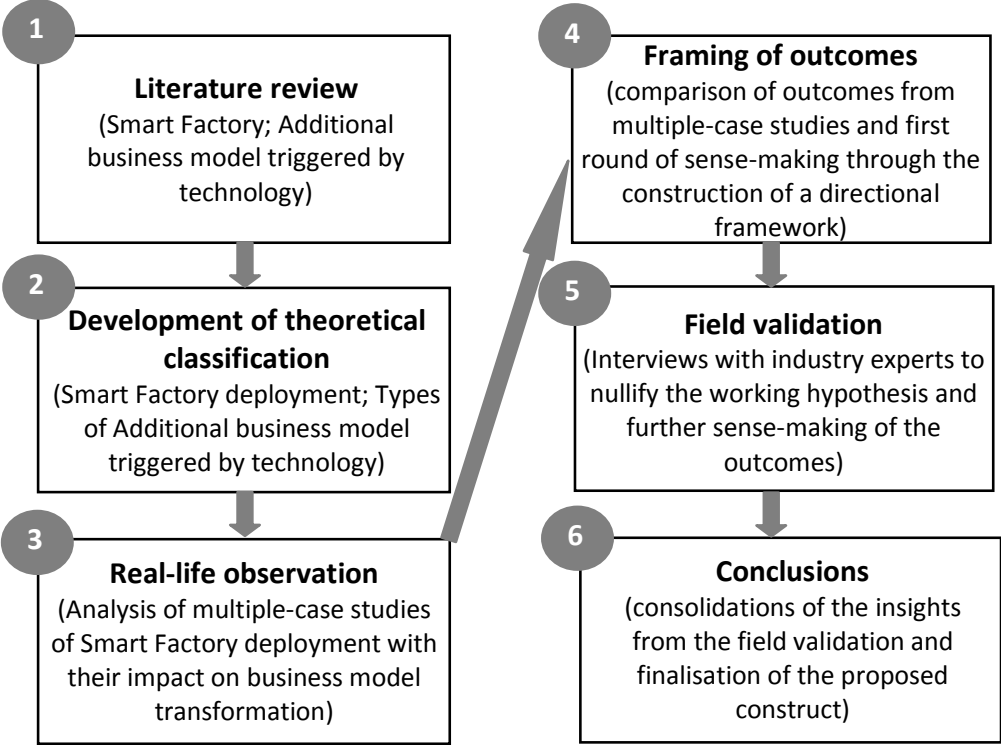

Source: authors' analysis

The analysis process was structured as follows:

- the smart factory trend was analyzed using the main reports and documents, and grouping them in order to identify key areas of development;

- within each area different cases were analyzed with the aim of defining emerging trends and opportunities within that area;

- the analysis of current literature was used to define the characteristics of the trajectories of innovative business models that facilitate the development of technology and digital business by creating value and preserving it.

The case studies $(\mathrm{N}=14)$ were selected within each area on the basis of their state of development (the project had to already be on the market) and the range of companies involved (min. 1, max. 4).

In order to study the cases, both secondary and primary data were collected and analyzed. This included documents and research reports in 
the field of smart factories, plus workshops, focus groups, interviews and meetings which were conducted with the assistance of experts and staff.

\section{Tab. 1: Primary (A) and Secondary (B) Sources}

\begin{tabular}{|c|c|c|}
\hline GROUP A & Involved subject/s & Time and place \\
\hline $\begin{array}{l}2 \text { workshops; in depth } \\
\text { interviews }\end{array}$ & $\begin{array}{l}\text { Tim, } \\
\text { Research and Innovation Center ICxT, } \\
\text { Bylogix, } \\
\text { Holonix spin-off (the Polytechnic } \\
\text { University of Milan) } \\
\text { Intesa Sanpaolo, } \\
\text { UnitoMesap mechatronic and advanced } \\
\text { production systems }\end{array}$ & $\begin{array}{l}\text { Turin, December } 2015 \\
\text { Turin, February } 2016\end{array}$ \\
\hline $\begin{array}{l}2 \text { workshops; } 2 \text { focus } \\
\text { groups }\end{array}$ & Smart Factory Cluster & $\begin{array}{l}\text { Turin, October } 2015 \\
\text { Bologna, December } 2015\end{array}$ \\
\hline $\begin{array}{l}2 \text { workshops; in depth } \\
\text { interviews }\end{array}$ & Smart Factory MIP Observatory & $\begin{array}{l}\text { Milan, July } 2015 \\
\text { Milan, December } 2015\end{array}$ \\
\hline 2 thematic meetings & $\begin{array}{l}\text { Centro di Ricerca ICxT, } \\
\text { ST Microelectronics, EBV, Intel, Huawai }\end{array}$ & $\begin{array}{l}\text { Turin, October } 2015 \\
\text { Turin, March } 2016\end{array}$ \\
\hline $\begin{array}{l}1 \text { conference; in depth } \\
\text { interviews }\end{array}$ & $\begin{array}{l}\text { CSMT Technological and Multi-sectorial } \\
\text { Services Center, } \\
\text { RISE Research and Innovation for Smart } \\
\text { Enterprise, } \\
\text { Beretta, Dallara, Givi, } \\
\text { MISE Economic Development Ministry }\end{array}$ & Brescia, June 2015 \\
\hline GROUP B & Details & Period of analysis \\
\hline Grey Literature & $\begin{array}{l}\text { Websites } \\
\text { National and international research } \\
\text { reports, internal business reports, } \\
\text { European documents }\end{array}$ & $\begin{array}{l}\text { September } 2015 \text { - } \\
\text { January } 2016\end{array}$ \\
\hline Academic Literature & Scientific papers & \begin{tabular}{|l|} 
September 2015 - \\
January 2016
\end{tabular} \\
\hline
\end{tabular}

Source: authors' elaboration

\section{Smart factory deployment}

Through the review of extant literature (consisting mostly of European and national guidelines, , i.e the 2014 "Industrie 4.0. Smart Manufacturing for the Future", and few existing academic papers, i.e. Hermann, Pentek, and Otto, 2016) it was possible to categorize smart factory technologies into macro groups, (see Figure 3 ) which have been arranged on a Euclidean space using three variables:

1) degree of connectivity of the Production System;

2) level of data gathering automation;

3) level of decision-making automation.

The first variable represents the degree of connectivity of the production system both internally and with its environment (y-axis), which can be defined as low, medium or high, depending on whether the interaction between machines and people in the production system was low (i.e. only few devices are connected) medium (i.e. most internal processes and devices are connected) or high (i.e. all the devices and processes are 
connected but many external processes and devices from stakeholders are also connected).

The second variable is the level of data gathering automation (x-axis), which can be defined as low, medium or high, depending on whether the data gathering is managed by people, partially automated or fully automated.

The third variable is the level of decision-making automation (z-axis), which can be defined as low, medium or high depending on the extent to which decisions are automated: low (decisions are mostly made by human interaction), medium (a number of low level decisions are completely made by algorithms), high (major decisions are managed by intelligent systems and humans are there to check for anomalies).

Fig. 3: Classification of enabling smart factory technologies

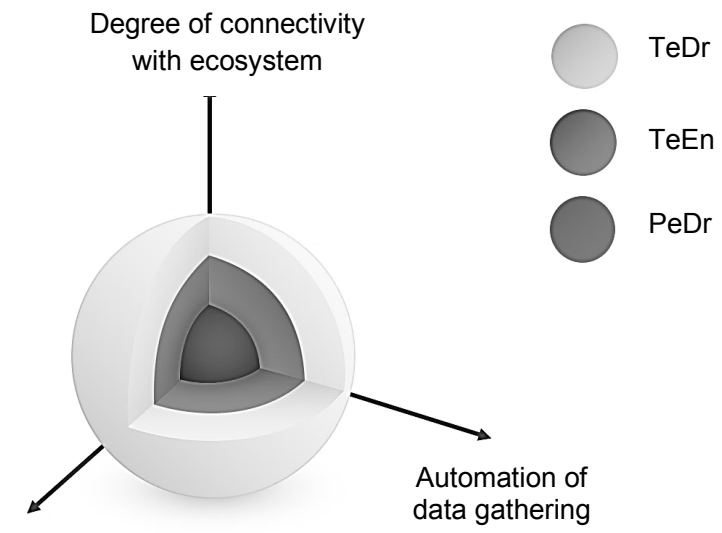

Automation of decision making

Source: authors' analysis

Three main areas (PeDr, TeEn, TeDr) have been identified and subsequently investigated using case studies in order to define emerging trends and unexplored (or poorly explored) areas of opportunity for companies.

In the People-driven (PeDr) area, the degree of connectivity with the ecosystem is low, the level of data gathering automation is low, and the level of decision-making automation is low. This area includes solutions, methods and tools for the sustainability of traditional, industrial business models, leveraging on technologies to build cost leadership through lower process variability, defects, and overall higher productivity. In this area, the relationship between people and machines is central, whereas the relationship among machines plays a marginal role. The trends that emerged from the analysis of projects in this area show a growing interest of businesses in relation to the safety and welfare of employees. The creation and sharing of knowledge is central and is carried out through new, smarter and more user-friendly interfaces for humans to interact 
sinergie Vol. 35, N. 103, 2017

among themselves. Smarter interfaces help individuals to become more efficient and increase their productivity. This may also be an opportunity for players in the telecommunications industry. In the PeDr area, opportunities will require the ability to (1) move from a multinational demand to a multinational offer, facilitating the collaboration of people with different cultural backgrounds and working styles, thus supporting an international working environment; (2) provide tools for the planning of common work, i.e. new operating environments; (3) support the change of decision profiles in the company (from connectivity to data management); (4) increase efficiency, which implies the creation of data without user involvement and of results in new interfaces. The financials support these trends. In 2014, 387 multinational companies created a total turnover of 12.206 billion EUR and provided employment for almost 32 million people. Smart working grew by $51 \%$ in Italy and $52 \%$ in the world overall. In Italy, only $17 \%$ of the companies have appointed a Chief Data Officer and only $13 \%$ a Data Scientist. In 2014, there were more than 100 Chief Data Officers in the Information Management Center (IMC) worldwide and the number has doubled since 2012.

In the Technology-enabled (TeEn) area, the degree of connectivity with the ecosystem is medium, the level of data gathering automation is medium or high, and the level of decision-making automation is medium. Technologies and systems for customized production are part of this area. Such solutions include smart objects that can collect data and interact with machines both within the factory and beyond it along the entire value chain. These machines, although capable of collecting data on their own, still do not interact with other machines. A common trait found within the sample of analyzed cases is focus on data as well as its acquisition, management, analysis, and security. Data becomes a crucial asset in the enterprise, although it is still characterized by a lack of common standards and protocols. A great deal of attention is dedicated to the efficiency of solutions in terms of space (delocalized interventions) and time (immediate action). However, there is a main need in this area for the creation of an environment system in which the data can be acquired, standardized, integrated, tested, displayed and interpreted. By starting from the need to identify new patterns through the combination of data that was previously difficult to find or non-existent, the possibility of using data which is derived not only from the reference sector and can also cover other areas becomes extremely interesting.

In the Technology-driven area ( $\mathrm{TeDr}$ ) the degree of connectivity of the ecosystem is high, the level of data gathering automation is high, and the level of decision-making automation is medium or high. Here, the level of collaboration among machines and between machines and people is high. This area concerns high efficiency production systems, innovative production processes and production systems which can adapt and evolve faster. Projects involving the creation of a shared environment belong to this area, where machines become centers for generating, collecting and exchanging data with other machines. Untapped potential is the target, which is reached through the development of innovative production systems that use algorithms and data to support decisions. The most 
obvious need, for this type of project, is the sharing of complex experiences and the resulting learning outcomes, as businesses and researchers work together at the convergence of industrial automation, robotics, big data analytics and networks. Answering to such need involves replicating the creation, interpretation and interaction of data on multiple machines, using data to improve the machine itself, distributing experience and learning to similar machines within or beyond the factory boundaries etc. Machines are integrated both upstream and downstream and people interact with them inside the factory. Considerable importance is attributed to the need to create common protocols for the management of different data as well as the enabling application software. It is worth noting that over $20 \%$ of Internet traffic comes from non-information devices and, by 2020, it is estimated that about 50 million machines will be connected to the Internet (Cisco, 2013).

\section{Business model innovation trajectories}

While the issue of innovation has always been primarily linked to products and services, the ability to develop a business model that best exploits the company's unique skills (Anthony, 2012) continues to attract the attention of researchers and practitioners. However, while extensive literature has been devoted to the creation of the company's original business model - see, for example, multiple business models (Brown and Joy 2002), the Canvas model (Osterwalder, 2005) and the Lean Start-up Methodology (Blank, 2012) - not as much attention has been paid to the subject of innovation in business models when a company is mature and must adapt to market changes.

Today, the business model is increasingly seen as a source of innovation, a vehicle for the transformation and renewal of a business (Zott et al., 2011), an important component of innovation concerning marketing and economic exchanges (Pisano et al., 2014; Amit and Zott, 2008; Magretta, 2002) to be managed in line with an organization, business processes (George and Bock, 2011) and strategy (D'aveni, 2015), and a key success factor in long-term performance (Chesbrough, 2010; Demil and Lecocq, 2010; Johnson et al., 2008; Sosna et al., 2010). Business Model Innovation may occur in three ways: (1) the business model can represent a stimulus for innovation (Mitchell and Coles 2003), introducing new work methods and changing the company's internal operation to increase efficiency without altering the essence of the product or service; (2) it is possible to innovate the business model through technological innovation with a demand pull approach (Baden-Fuller and Haefliger, 2013) that propels the company into new markets with the role of first mover as typically occurs with large companies. Finally, (3) in order to maintain their leadership in the corporate market, companies can develop secondary products or value propositions or they can adapt existing products to different contexts. This kind of "disruptive innovation" often leads to the renewal of a business (Christensen, 1997), as the business model is reconfigured in order to meet new consumer needs (Teece, 2010).
Paola Pisano Marco Pironti Lia Tirabeni Davide Sola

Giovanni Scarso Borioli

The developing role of

telecommunication firms from technology enablers to strategic players in the smart factory 
sinergie Vol. 35, N. 103, 2017

Regardless of how innovation in the business model occurs, its structure (Teece, 2010) must enable the company to provide value to all its customers whilst protecting its competitive position. This requires a business model that is flexible enough to allow the company to anticipate problems, identify and exploit opportunities, correct projects which are going astray and respond to social and technological change (Delmar and Shane, 2003). A model, which can create and defend values, seizing opportunities, adapting and modifying itself, according to market needs. Such a business model cannot be separated from an experimental path (McGrath, 2010) that reinforces the idea that companies need not be limited to a single business model; instead, in order to adapt to changing circumstances, they can utilise several models at the same time (BadenFuller and Morgan, 2010).

These observations support the view that defining, modifying and adapting business models is a complex art which requires further theoretical research as well as practical experimentation by business entrepreneurs. In recent years, new business models have emerged in the field of digital technologies to support and protect innovation. Examples of this include the long tail model of Anderson (2006) and the open models of Chesbrough (2006a). At the same time, new ways of adapting business models to market opportunities have been described and applied (Reeves, Zeng and Venjara, 2015).

Figure 4 represents emerging trajectories of business model innovation. It shows how business model innovation can be achieved from the extension of the sustainability of the existing business model of a firm thanks to the increased availability and quality of data coupled with an increased ability of insight generation.

Fig. 4: Classification of additional business models triggered by digital technologies deployment

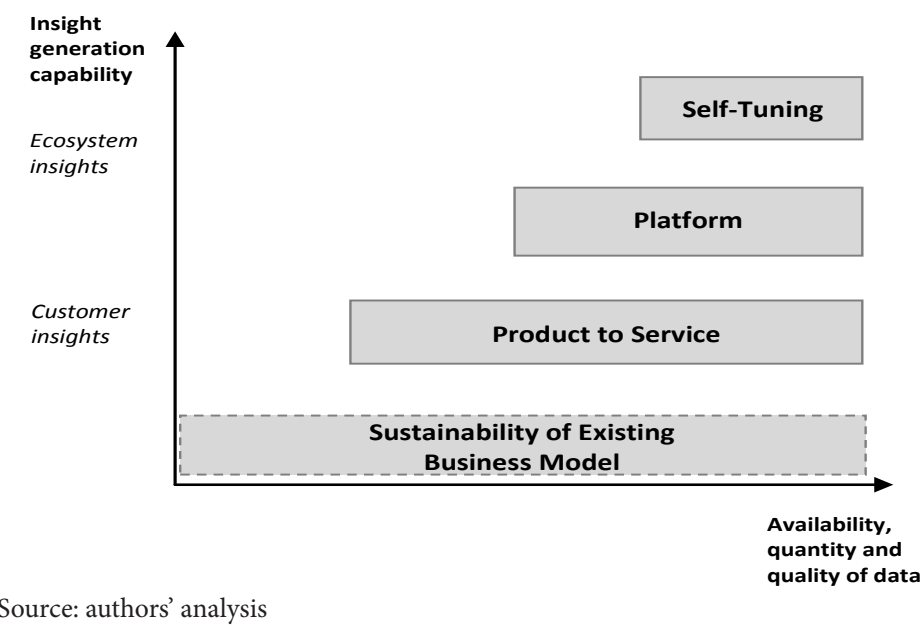

The extension of the sustainability of the business model takes on the form of improvements in various parts of the business model without 
fundamentally changing its logic, therefore aiming at enhancing each component with the objective of achieving continuous improvement.

Figure 4 also indicates that there are three ways in which new and flexible business models can be developed. These are far more transformational, and impact one or more components of the business model and trigger a wider change.

The first two new options (the product-service model and the platform model) are driven by technology, while the third is linked to a new way of approaching the evolution of the business model (the self-tuning model). The next sections of the paper will be focused on these new options, thus leaving the extension of the existing business model aside.

\subsection{The product to service model}

Technological innovation, which allows the creation of intelligent and interconnected objects or devices, is enabling new business models in which the product becomes a service. The emergence of such products, where connected software and operating systems are integral components, is stimulating new principles of product development and redrawing the functions of the business model.

Such connected products, often offered in a service mode, can collect data on how customers are using them, which allows manufacturers to analyze customer behavior and refine the product to more closely meet their needs. In addition, services that were once offered to complement the product (such as customer care) are now incorporated into the product itself. The management and the life-cycle maintenance of these products become the responsibility of the manufacturer, who carries the costs but also benefits - of the value placed upon these services by customers. An example of this enhancement of products to incorporate services is represented by the way Xerox went from selling copiers to renting copiers with built-in sensors that facilitate accurate billing and facilitate the timely sale and provision of consumables (Heppelmann and Porter, 2015). This type of product enhancement strengthens the bond between the company and its customers, who are now not just buying a product but also receiving a service. It also changes the company's value chain, which now includes upstream and/or downstream activities of production, and has implications for its financial structure and customer management (Caution et al., 2014). To support a business model of this nature, companies need to have an accurate understanding of how customers use their products. They must learn to monitor not only their use but also customer satisfaction.

Finally, as the product becomes a service, the business model will change as regards costs, the distribution channel and the relationship with the customer. For example, the responsibility for product maintenance and its related costs will be borne by the producer. This has a significant impact, especially in cases where multiple customers share the same product. An example of this is Smoove, a French bike-sharing service that has designed its smart bicycles with features such as drive shafts rather than chains, puncture-resistant tyres and anti-vandal nuts on the wheels to increase reliability and prevent theft (Heppelmann and Porter, 2015).
Paola Pisano Marco Pironti Lia Tirabeni Davide Sola

Giovanni Scarso Borioli

The developing role of
The

telecommunication firms

from technology enablers to

strategic players in the smart factory 
sinergie Vol. 35, N. 103, 2017

In general, the product-service model drives a profound change at all levels of the business model. Looking at "key activities" component of the business model, new types of activity emerge, linked to the creation, management and maintenance of the product. Even more importantly new professional roles, related to data management like Chief Data Officer, are added. The cost structure and revenue streams change, as data management generates costs and sales generate new revenue. The relationship with customers, which also changes to become continuous and bi-directional, is particularly important. Finally, new customer segments are accessed, benefitting from either enhanced or simplified value propositions.

\subsection{The platform model}

Technologically advanced companies in this area begin to play a dual role. They are not only actors within their industry, providing value propositions to their segments of customers, but also facilitators, enabling other players within the sector to innovate their business model. A number of companies have developed a technology platform which provides not a product but a business support service.

Companies like eBay, IBM, Autodesk, PTC, Materialise, Stratasys and 3D Systems have exploited the value of a platform model that facilitates both their own businesses and connections with other companies, allowing new trends to develop. For these companies, the developing trend is $3 \mathrm{D}$ printing (D’Aveni, 2015).

However, what is less replicable is the creation of an infrastructure that will facilitate the company's business (a) by promoting collaboration among key stakeholders such as suppliers, customers and producers, (b) through the creation of new opportunities by monitoring transactions and recording a high volume of information and data, and (c) by disseminating innovative trends and new technologies within different sectors.

The relationship networks and data that are generated through the platform business model constitute valuable assets for the company. Not only can the information be provided by analyzing millions of transactions drive improvement within the existing business but it can also create new sources of value propositions mediated through the platform's networks. An example of this is the way Amazon decides which products to sell with brand Amazon on its platform. The company, analyzing transactions on its platform, has identified the most sold products and has consequently marked them with its logo.

\subsection{The Self-Tuning model}

The self-tuning model, proposed by Reeves et al. (2015), is exemplified by Alibaba, a start-up company which has become a dominant player, leveraging the basic principles of algorithms to continuously retune or refine the strategy, organization and business model of the enterprise. In recent years, technological development has brought about important changes not only at the macroeconomic level, but also at the microeconomic level. The convergence of industries has led to the establishment of mixed 
business models which adapt resources, processes and structures based on the real-time analysis of the behaviors and needs of users by using advanced algorithms. Companies like Google, Netflix and Amazon have become very good at collecting data on the user's habits and desires and, as a result, producing offers which the consumer is likely to find interesting.

Technological solutions can create a sound basis for the definition of business models that continuously evolve to exploit the strategic opportunities presented by the business environment. In this way, vision and business models are no longer fixed axes around which the entire organization is created. Instead, structure, systems, processes and culture keep evolving as a result of the organization's successes and failures. Experimentation and innovation, which are normally focused only on products and services, are also applied to the business model. In this way it becomes possible to monitor, analyze and take action and therefore continuously improve the model by testing it (discovering what works), and adapting it according to the surrounding environment. For example, with new customers the experimental modulation is high and the influence on consumer preferences (i.e., trying not only to understand customer preferences regarding current products, but also to exploit emerging preferences with new products and services).

The table below, based on a review of the literature, summarizes the ways in which digital technologies have enabled the development of innovative business models.

Tab. 1: Business models (BM) enabled by digital technologies

\begin{tabular}{|c|c|c|c|}
\hline Model & $\begin{array}{l}\text { Focus and Value } \\
\text { Proposition }\end{array}$ & Author/s & BM Innovation \\
\hline Product-service & $\begin{array}{l}\text { BM increases the value } \\
\text { proposition of the } \\
\text { product by expanding it } \\
\text { to become a service }\end{array}$ & $\begin{array}{l}\text { Heppelmann and } \\
\text { Porter }(2015)\end{array}$ & $\begin{array}{l}\text { The suppliers related to new product features are } \\
\text { key partners } \\
\text { - New activities related to new product features are } \\
\text { key activities } \\
\text { - New figures related to data are key resources } \\
\text { - Structure data management generates costs } \\
\text { - flows revenues of new activities are not related to } \\
\text { the sale } \\
\text { - Channels online } \\
\text { - Customer Relationship is continuous and two- } \\
\text { way }\end{array}$ \\
\hline Platform & $\begin{array}{l}\text { BM enables role } \\
\text { development within the } \\
\text { industry from economic } \\
\text { actor to facilitator of } \\
\text { technology and trends }\end{array}$ & $\begin{array}{l}\text { D’Aveni (2015), } \\
\text { Patuano (2015) }\end{array}$ & $\begin{array}{l}\text { - The relationship with key partners changes by } \\
\text { modifying the company's position in the chain } \\
\text { - Key activities are related to platform management } \\
\text { - The channel is the platform } \\
\text { - Revenues Flows are the sale of information and } \\
\text { data developed by exchanges within the platform }\end{array}$ \\
\hline TSelf-Tuning & $\begin{array}{l}\text { BM identifies business } \\
\text { opportunities r by } \\
\text { continuously adapting } \\
\text { to consumers' new needs }\end{array}$ & $\begin{array}{l}\text { Reeves, Zeng e } \\
\text { Venjara (2015) }\end{array}$ & $\begin{array}{l}\text { - All aspects of the business model change } \\
\text { according to identified opportunities } \\
\text { - Ability to manage multiple business models } \\
\text { within the same company }\end{array}$ \\
\hline
\end{tabular}

Source: authors' analyses

\section{Case analysis}

Table 2 is a summary of the cases that have been analyzed. First, we focused our effort in identifying the recipient that is adopting the smart factory approach for each case, then we observed the presence and role
Paola Pisano Marco Pironti Lia Tirabeni Davide Sola

Giovanni Scarso Boriol The developing role of telecommunication firms from technology enablers to strategic players in the smart factory 
sinergie Vol. 35, N. 103, 2017

of the technology partners. Most importantly, we classified each project according to its smart factory deployment approach and type of business model trajectory.

Tab. 2: Analyzed Smart Factory projects

\begin{tabular}{|c|c|c|c|c|c|c|}
\hline Project & Objectives & Recipient & $\begin{array}{l}\text { Technology } \\
\text { partners }\end{array}$ & $\begin{array}{c}\text { Telco } \\
\text { Presence }\end{array}$ & $\begin{array}{l}\text { Smart } \\
\text { Factory } \\
\text { Deployment } \\
\text { approach }\end{array}$ & $\begin{array}{l}\text { Recipient } \\
\text { Business } \\
\text { Model } \\
\text { Trajectory }\end{array}$ \\
\hline $\begin{array}{l}\text { Smart Porsche } \\
\text { Connect }\end{array}$ & $\begin{array}{l}\text { Improve connect driver } \\
\text { and vehicle to enhance } \\
\text { safety, security and the } \\
\text { driver's experience }\end{array}$ & Porsche & Vodafone & Yes & TeEn & Sustainability \\
\hline $\begin{array}{l}\text { Piaggio } \\
\text { Multimedia } \\
\text { Platform }\end{array}$ & $\begin{array}{l}\text { Provision and analysis } \\
\text { of vehicle and driver } \\
\text { performance to enhance } \\
\text { driver experience }\end{array}$ & Piaggio & Dquid & No & $\mathrm{TeDr}$ & Sustainability \\
\hline Bag2Go & $\begin{array}{l}\text { Synchronize a suitcase } \\
\text { with a passenger's flight } \\
\text { itinerary and enable it to } \\
\text { be tracked }\end{array}$ & Rimowa & Deutsche Telekom & Yes & TeEN & $\begin{array}{l}\text { Product to } \\
\text { Service }\end{array}$ \\
\hline $\begin{array}{l}\text { Connected } \\
\text { Industry } \\
\text { Platform }\end{array}$ & $\begin{array}{l}\text { Provide secure end-to- } \\
\text { end communication for } \\
\text { networked production }\end{array}$ & Belden & $\begin{array}{l}\text { Deutsche Telekom, } \\
\text { Infineon } \\
\text { Technologies, } \\
\text { WIBU Systems }\end{array}$ & Yes & $\mathrm{TeDr}$ & $\begin{array}{l}\text { Product to } \\
\text { Service early } \\
\text { Platform }\end{array}$ \\
\hline $\begin{array}{l}\text { Dynamic } \\
\text { Maintenance } \\
\text { Management }\end{array}$ & $\begin{array}{l}\text { Rapid management } \\
\text { and optimization } \\
\text { of the rolling stock } \\
\text { maintenance process. }\end{array}$ & Trenitalia & Sap & No & $\mathrm{TeDr}$ & Sustainability \\
\hline Enjoy & $\begin{array}{l}\text { Rent a vehicle with a } \\
\text { smartphone in a faster } \\
\text { and easier way }\end{array}$ & Fiat & $\begin{array}{l}\text { Vodafone, FIAT, } \\
\text { Frecciarossa, } \\
\text { ENI, Piaggio }\end{array}$ & Yes & $\mathrm{TeDr}$ & $\begin{array}{l}\text { Product to } \\
\text { Service early } \\
\text { Platform }\end{array}$ \\
\hline Pest Connect & $\begin{array}{l}\text { Deployment of sensors, } \\
\text { RFId technology to } \\
\text { connect pest devices }\end{array}$ & Rentokil & $\begin{array}{l}\text { Google, } \\
\text { Vodafone }\end{array}$ & Yes & TeEn & $\begin{array}{l}\text { Sustainability } \\
\text { early Product to } \\
\text { Service }\end{array}$ \\
\hline My Essentials & $\begin{array}{l}\text { Deployment of Machine- } \\
\text { to-Machine technology } \\
\text { to feed data inputs from } \\
\text { Pest Connect first, then } \\
\text { other devices such as } \\
\text { sanitary, safety and } \\
\text { environment devices }\end{array}$ & Rentokil & $\begin{array}{l}\text { Google, } \\
\text { Vodafone }\end{array}$ & Yes & $\mathrm{TeDr}$ & $\begin{array}{l}\text { Product to } \\
\text { service early } \\
\text { Platform }\end{array}$ \\
\hline $\begin{array}{l}\text { Elevator } \\
\text { Maintenance }\end{array}$ & $\begin{array}{l}\text { Improve the efficiency } \\
\text { and speed of elevator } \\
\text { maintenance service }\end{array}$ & $\begin{array}{l}\text { Schindler } \\
\text { Elevator } \\
\text { Corporation }\end{array}$ & Verizon & Yes & $\mathrm{PeDr}$ & Sustainability \\
\hline $\begin{array}{l}\text { Smart Port } \\
\text { Logistics }\end{array}$ & $\begin{array}{l}\text { Optimize traffic } \\
\text { flows and logistics } \\
\text { management in order to } \\
\text { allow larger quantities of } \\
\text { goods to be transshipped } \\
\text { to port areas }\end{array}$ & $\begin{array}{l}\text { Hamburg } \\
\text { Port } \\
\text { authority }\end{array}$ & $\begin{array}{l}\text { ADAC, Hoyer } \\
\text { Unternehmensgruppe, } \\
\text { Deutsche Telekom, } \\
\text { Sap }\end{array}$ & Yes & $\mathrm{TeDr}$ & $\begin{array}{l}\text { Early } \\
\text { Platform }\end{array}$ \\
\hline Director & $\begin{array}{l}\text { Increase work } \\
\text { performance and } \\
\text { monitoring through } \\
\text { augmented reality }\end{array}$ & Schlumberger & Wearable Intelligence & No & $\mathrm{PeDr}$ & Sustainability \\
\hline I-Protect & $\begin{array}{l}\text { Increase the safety of law } \\
\text { enforcement through } \\
\text { the IoT }\end{array}$ & Beretta & Intellitronika & No & $\mathrm{PeDr}$ & Sustainability \\
\hline $\begin{array}{l}\text { Aircraft } \\
\text { Maintenance }\end{array}$ & $\begin{array}{l}\text { Optimize work } \\
\text { processes and share } \\
\text { knowledge by utilizing } \\
\text { augmented reality }\end{array}$ & Airbus & $\begin{array}{l}\text { Fraunhofer IGD, } \\
\text { Deutsche Telekom }\end{array}$ & Yes & PeDr & Sustainability \\
\hline $\begin{array}{l}\text { Ready for } \\
\text { Connected } \\
\text { Industry }\end{array}$ & $\begin{array}{l}\text { Advanced automation } \\
\text { enhancement through } \\
\text { predictive IoT } \\
\text { maintenance }\end{array}$ & Bosch & Solair & No & $\mathrm{TeDr}$ & $\begin{array}{l}\text { Early } \\
\text { Platform }\end{array}$ \\
\hline
\end{tabular}

Source: authors' analysis

The table provides several insights that we believe are particularly interesting for the understanding of this domain and are discussed in the final section of this paper. 


\section{Results and discussion}

The data synthetized in table 2 provide three major findings, which are represented in figure 5. This representation was built by cross-referencing the pairing of Smart Factory deployment approach with the business model innovation adopted by the recipient firm in each analyzed case.

The first finding is that the adoption of the smart factory technologies can not only foster performance improvements within existing business models, but it can also induce business model innovation. This represents a paradigm shift compared to how digital technologies have been envisioned in the industry over the past decades.

The second finding is that there seems to be a directionality linking the stages of development of smart factory deployment and the types of innovative business model options which are unlocked. In particular, the higher the degree of evolution of smart factory deployment, from PeDr, to TeEn, to TeDr, the more distant business model innovation trajectories are from traditional manufacturing ones, ranging from Product-to-service, to Platform, to Self-Tuning models.

Finally, the study shows that the role of Telecoms as strategic change agents, and consequently their opportunities for a relevant share of new market opportunities, is increasingly unlocked by following the same trajectory of smart factory deployment evolution and business model innovation. In other words, the deeper the smart factory paradigm penetrates the DNA of adopting companies, the more strategic is the potential role of Telcos, and consequently their relevance within the new, disrupted value chain. This represents a unique opportunity for Telcos to invest in the development of know-how, expertise and customer intimacy, which can be seen as one of the (few) available levers to contrast the increasing commoditization of Telcos' core service, i.e. connectivity.

While this study is exploratory in nature and has looked into a comparatively small sample of cases, and therefore cannot claim to have reached a high degree of validity and replicability, it has achieved the initial objective of developing a model of evolution which can trigger more extended studies in order to:

- further operationalize both identified dimensions (e.g. smart factory deployment evolution and business model innovation trajectories);

- expand the size of the sample of cases to increase the degree of validity, thus potentially complementing the methodology with quantitative surveys to increase statistical significance;

- follow a few more relevant cases longitudinally over a longer period of time, adopting Grounded Theory approaches, in order to develop a more granular theoretical understanding of the phenomena under study.
Paola Pisano

Marco Pironti

Lia Tirabeni

Lia Tiraben

Giovanni Scarso Borioli

The developing role of

telecommunication firms

from technology enablers to

strategic players in the smart factory 
sinergie

italian journal of management
Vol. 35, N. 103, 2017

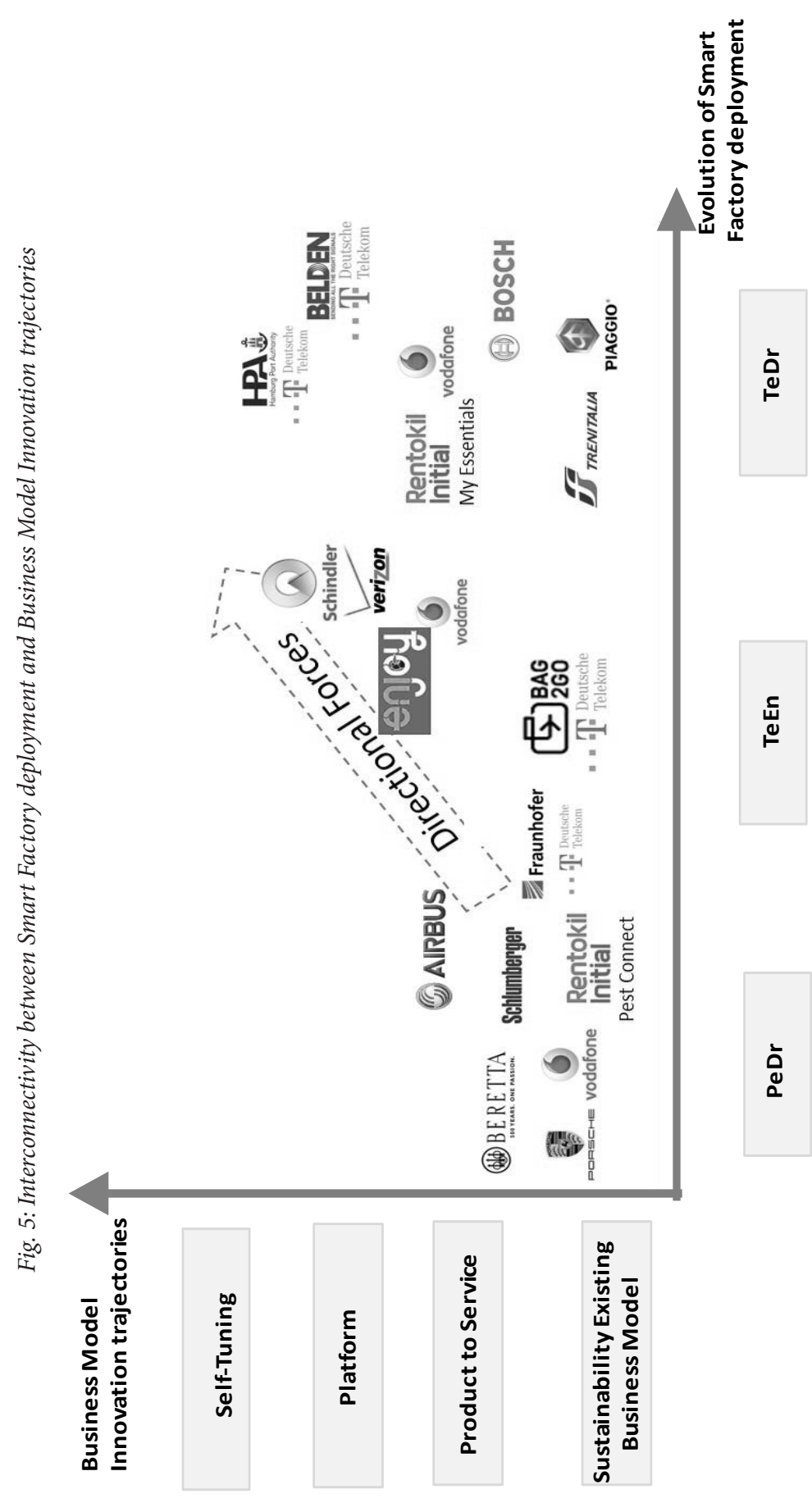


ALMADA-LOBO F (2015), "The Industry 4.0 revolution and the future of Giovanni Scarso Boriol Manufacturing Execution Systems (MES)", Journal of Innovation telecommunication firm Management, vol. 3, n. 4, pp. 16-21.

ANDERSON C. (2006), The Long Tail: Why the Future of Business Is Selling Less of telecommunication firms from technology enablers to
strategic players in the smart More, Hyperion, New York.

ANTHONY S. (2012), "Kodak and the Brutal Difficulties of Transformation", Harvard Business Review, Blog, $17^{\text {th }}$ anuary.

BADEN-FULLER C., MORGAN M. (2010), "Business models", Long Range Planning, vol. 43, n. 2, pp. 156-171.

BADEN-FULLER C., HAEFLIGER S. (2013) "Business Models and Technological Innovation”, Long Range Planning, vol. 46, n. 6, pp. 419-426.

BLANK S. (2012), The Startup Owner's Manual, K\&S Ranch, Pescaredo, California. BROWN M.E., GIOIA D.A. (2002), "Making things click: Distributive leadership in an online division of an offline organization", The Leadership Quarterly, vol. 13, n. 4, Aug, pp. 397-419.

CAUTELA C., PISANO P., PIRONTI M. (2014), “The emergence of new networked business models from technology innovation: an analysis of 3-D printing design", International Entrepreneurship and Management Journal, vol. 10, n. 3, pp. 487-501.

CHESBROUGH H. (2006a), Open Business Models: How to Thrive in the New Innovation Landscape, Harvard Business School Press, Cambridge (MA).

CHESBROUGH H.W. (2010) "Business model innovation: opportunities and barriers”, Long Range Planning, vol. 43, n. 2-3, pp. 354-363.

CHRISTENSEN C.M. (1997), The Innovator's Dilemma: When New Technologies Cause Great Firms to Fail, Harvard Business School Press, Boston, MA.

CISCO SYSTEMS (2013), "Cisco Industrial Smart Solution: la connessione tra fabbrica e azienda", white paper.

D'AVENI R. (2015), “The 3-D Printing Revolution”, Harvard Business Review, May, n. 5 , pp. $40-48$

DELMAR F., SHANE S. (2003), "Does business planning facilitate the development of new ventures?”, Strategic Management Journal, vol. 24, n. 12, pp. 1165-1185.

DEMIL B., LECOCQ X. (2010) "Business model evolution: in search of dynamic consistency", Long Range Planning, vol. 43, n. 2-3, pp. 227-246.

EISENHARDT K.M. (1989b), "Building theories from case study research", Academy of Management Review, vol. 14, n. 4, pp. 532-550.

“Top 10 Strategic Technology Trends” (2015), Gartner's Report.

GEORGE G., BOCK A.J. (2011), "The Business Model in Practice and its Implications for Entrepreneurship Research", Entrepreneurship Theory and Practice, vol. 35, n. 1, pp. 83-111.

GOODNESS E. FOONG K., WALLIN L, RUUD K. (2015), Magic Quadrant for Managed Machine-to-Machine Services, Worldwide, 26 August.

"Great expectations: The evolution of the chief data officer" (2015), PwC, Report.

HERMANN M., PENTEK T., OTTO B. (2016) "Design Principles for Industrie 4.0 Scenarios", $4^{\text {th }}$ Hawaii International Conference on System Sciences, IEEE Computer Society, pp. 3928-3937.

"IDC Predictive Security in the 3rd Platform Era" (2015), Nuovi scenari della sicurezza IT nell'Era della Terza Piattaforma, 11 marzo, Milano. 
YIN R.K. (2008), Case study research: Design and methods, vol. 5, Sage Publications, Incorporated.

"Industrie 4.0. Smart Manufacturing for the Future", (2014), Germany Trade \& Invest, Report.

"Industry 4.0 The New Industrial Revolution: How Europe Will Succeed", (2014) March, Roland Berger Strategy Consultants.

JOHNSON G., SCHOLES K., WHITTINGTON R. (2008), Exploring Corporate Strategy Text and Cases, Edition 8, Essex: Financial times prentice hall Pearson education.

LARSSON R. (1993), "Case survey methodology: Quantitative analysis of patterns across case studies", Academy of Management Journal, vol. 36, n. 6, pp.1515-1546.

MAGRETTA J. (2002), "Why Business Models Matter", Harvard Business Review, May, n. 5, pp. 86-92.

MARKIDES C. (2006), “Disruptive Innovation: in need of better theory?”, Journal of Product Innovation Management, vol. 23, n. 1, pp. 19-25.

McGRATH R. (2010) “Business models: a discovery driven approach", Long Range Planning, vol. 43, n. 2-3, pp. 247-261.

"Mercato Digitale", (2015), Assinform, Rapporto.

MITCHELL D., COLES C. (2003), "The ultimate competitive advantage of continuing business model innovation", Journal of Business Strategy, vol. 24, n. 5, pp. 15-21.

NUMAGAMI T. (1998), “The infeasibility of invariant laws in management studies: A reflective dialogue in defense of case studies", Organization Science, vol. 9, n. 1, pp. 2-15.

OSTERWALDER A., PIGNEUR Y., TUCCI C.L. (2005), "Clarifying Business Models: Origins, Present, and Future of the Concept", Communications of the Association for Information Systems, vol. 16, n. 1, pp. 1-25.

PATUANO M. (2015), "Un nuovo modello di business per le Telco", Harvard Business Review Italia, Dicembre, n. 12, pp. 85-97.

PISANO P., PIRONTI M., CHRISTODOULOU P. (2014), “The open long tail model between new culture and digital technology”, Sinergie, n. 93, pp. 8093.

PORTER M.E., HEPPELMANN J.E. (2015), “How Smart Connected Products Are Transforming Companies", Harvard Business Review, October, n. 10, pp. 96-114.

RADZIWON A., BILBERG A, BOGERS M., MADSEN E.S. (2014) "The Smart Factory: Exploring Adaptive and Flexible Manufacturing Solutions", Procedia Engineering, vol. 69, n. 1, pp. 1184-1190

REASON P., GOODWIN B.C. (1999) "Toward a Science of Qualities in Organizations: lessons from complexity theory and postmodern biology", Concepts and Transformations, vol. 4, n. 3, pp. 281-317.

REEVES M., ZENG M., VENJARA A. (2015), "The Self-Tuning Enterprise", Harvard Business Review, June, n. 6, pp. 76-83.

REEVES M. LOVE, TILLMANS (2012), "Your Strategy Needs A Strategy”, Harvard Business Review, September, n. 9, pp. 1-9.

SOSNA M., TREVINYO-RODRIGUEZ N.R., VELAMURI S.R. (2010) "Business Model Innovation through Trial-and-Error Learning: The NaturHouse Case", Long Range Planning, vol. 43, n. 2-3, pp. 383-407. 
TEECE D.J. (2010), “Business models, business strategy, and innovation”, Long Range Planning, vol. 43, n. 2-3, pp. 172-194.

Paola Pisano

Marco Pironti

Lia Tirabeni

ZOTT C., AMIT R. (2008), “The fit between product market strategy and business avide Sola model: implications for firm performance", Strategic Management Journal, vol. 29, n. 1, pp 1-26.

ZOTT C., AMIT R., MASSA M. (2011), “The business model: recent developments Giovanni Scarso Borioli The developing role of telecommunication firms from technology enablers to strategic players in the smart and future research”, Journal of Management, vol. 37, n. 4, pp. 1019-1042.

\title{
Internet references
}

\author{
www.gartner.com \\ www.gtai.de \\ www.rolandberger.it \\ www.cisco.com \\ www.efra.eu \\ $w w w$ fabbricaintelligente.it \\ www.idc.com \\ http://iotuk.org.uk/ \\ www.pwc.com \\ www.hbr.org
}

\section{Academic or professional position and contacts}

\section{Paola Pisano}

Ph.D. in Management

University of Turin - Italy

e-mail: pisano@di.unito.it

\section{Marco Pironti}

Associate Professor of Management

University of Turin - Italy

e-mail: pironti@di.unito.it

\section{Lia Tirabeni}

PhD Researcher in Sociology

University of Turin - Italy

e-mail: lia.tirabeni@unito.it

\section{Davide Sola}

Associate Professor of Strategy

ESCP Europe Business School - London

e-mail: dsola@escpeurope.eu

\section{Giovanni Scarso Borioli}

Assistant Professor of Operations Management

ESCP Europe Business School - London

e-mail: gscarsoborioli@escpeurope.eu

sinergie
italian journal of management

ISSN 0393-5108 DOI 10.7433/s103.2017.10 pp. 199-217 